\title{
The Modeling of Tsunami Wave Run-Up and Vulnerability Zone Analysis In Cipatujah, Tasikmalaya District
}

\author{
Tamara Centong Mandey ${ }^{*}$, Aris Ismanto ${ }^{1}$, Denny Nugroho Sugianto ${ }^{1}$, Purwanto ${ }^{1}$, Rikha \\ Widiaratih $^{1}$, dan Gentio Handoyo ${ }^{2}$
}

\author{
${ }^{1}$ Department of Oceanography, Faculty of Fisheries and Marine Sciences, Diponegoro University, Semarang, \\ Indonesia, Prof. H. Soedarto, SH Street, Tembalang, Telp/fax (024) 7474698 Semarang 50275 \\ ${ }^{2}$ Faculty of Defence Technology, Republic Indonesia Defence University \\ IPSC Sentul Area, Sukahati, Citeureup District, Bogor, Jawa Barat 16810 \\ Email : *tamara.chend@gmail.com
}

\begin{abstract}
Cipatujah is a sub-district in Tasikmalaya Regency, West Java Province, Indonesia, which is one of the areas affected by significant damage due to tectonic activity in the southern region of Java, namely an earthquake with a magnitude of 7.7 magnitude and West Java tsunami in 2006 after Nusa Kambangan and PangandaranThe purpose of this study is to estimate the tsunami travel time, wave heights distribution, coverage areas, and vulnerability zone based on the Java 17 July 2006 earthquake scenario in Cipatujah, Tasikmalaya Regency. The method used in this study is quantitative and requires bathymetry data, high points, earthquake parameters of July 17, 2006, tidal data, RBI maps, and land use data. Tsunami modeling with numerical simulations using COMCOT v 1.7 and MATLAB software, also Arc Map for mapping tsunami coverage and vulnerability zone areas. Based on data processing, it was found that the maximum wave speed of $3.92 \mathrm{~m} / \mathrm{s}$. In the 27 th minute, the waves had reached the Cipatujah region, with a maximum run-up height of 6.115 meters and a maximum tsunami range on the land of 1.891 meters. The area affected by the tsunami based on the processing of tsunami coverage data in Cipatujah totals $11.64 \mathrm{~km} 2$. Whereas for tsunami vulnerability zone in Cipatujah, it is divided into 3 categories, namely low hazard zone, medium hazard zone, and high hazard zone. This indicates that the Cipatujah region is included in a high tsunamiprone zone. Based on the results of verification and validation with an RSR value of 0,073, then it is assumed that the height of the run-up model is sufficient by the run-up data that occurred during the event.
\end{abstract}

Keywords : COMCOT, Tsunami, vulnerability zone, cipatujah, run-up

\section{INTRODUCTION}

Tsunami is one of the natural phenomena where ocean waves propagate in all directions due to impulsive disturbance on the seabed ${ }^{21}$. Impulsive disturbances are caused by changes in the shape of geological structures on the seabed mainly in a short period, which is usually caused by tectonic plate movements, volcanoes erupting on the seabed, and also landslides on the seabed. Tsunamis are also natural phenomena including catastrophic disasters because they cause significant damage and damage in coastal and coastal areas to the mainland especially in countries that have active tectonic plates ${ }^{16}$.

Indonesia is one of the countries located at the confluence of 3 active tectonic plates namely the Eurasian Plate, the Australian Plate, the Pacific Plate ${ }^{3}$. Based on data from the Climatology and Geophysics Meteorology Agency (BMKG), the territory of Indonesia has an earthquake history of up to 244 events since the years $416-2018$ that was able to cause a tsunami wave. At least eleven tsunami disasters have occurred in Indonesia that have caused more than 100 lives, namely the tsunami in Banda Banda (1674); P. Bali (1815); Lampung and Banten (1883); P. Banda (1899); Flores (1992); Banyuwangi, East Java (1994); Aceh (2004); West Java (2006); Mentawai (2010); PaluDonggala (2018); Lampung and Banten (2018). Areas with a high tsunami threat can be seen scattered in almost all regions of Indonesia ${ }^{22}$.

Cipatujah is a sub-district in Tasikmalaya Regency, West Java Province, Indonesia, which is one of the areas that are prone to tsunamis. The location of the coast of Cipatujah in the southern part of the island of Java results in this area facing the Indian Ocean where there is a subduction zone or zone subduction zone between continental plates and oceanic plates which can cause earthquakes. Based on previous research, it was noted that Cipatujah was a region that was affected by significant damage due to 
tectonic activity in the southern region of Java, namely an earthquake with a magnitude of 7.7 magnitude and West Java tsunami in 2006 after Nusa Kambangan and Pangandaran with each run-up height. $20 \mathrm{~m}$ and $3-8 \mathrm{~m}^{19}$.

Earthquake and tsunami events that have occurred are very potential to occur again in the future. Therefore, research on tsunami modeling uses numerical simulations as well as the making of a range map and tsunami vulnerability zone map on the Cipatujah Tasikmalaya Coastal based on the West Java Earthquake scenario on July 17, 2006, which can later be used as a supply of supporting information data for disaster mitigation.

\section{MATERIAL AND METHODS}

The research material needed in this study is primary and secondary data which is used as input in modeling the tsunami propagation. Primary data and is the main data in a study, while secondary data is supporting data in a study ${ }^{11}$. The primary data used is the beach slope data in units of degrees which is the result of direct measurement in the field. While secondary data used as land use classifications include 1) Rupa Bumi Indonesia Map of Tasikmalaya Regency scale of 1: 25,000 in 2018 BIG publication; 2) Bathymetry data of GEBCO 30 arc-second scale BODC publication; 3) BATNAS waters data in Tasikmalaya Regency scale of 6 arc-second BIG publication; 4) DEMNAS data of Tasikmalaya Regency area scale of 0.27 arc second BIG; 5) BIG digital tidal data at Pamayangsari Tidal Station in January October 2019; 6) Historical earthquake data and earthquake parameters south of Java Island by USGS; 7) Land use classification data from BAPPEDA of Tasikmalaya Regency in 2019.

The method used in this research is a quantitative method. The quantitative method is a data collection technique that is presented in the form of numbers and can be calculated qualitatively ${ }^{18}$. In this study, tsunami modeling uses numerical simulations using COMCOT v 1.7 software, then the results are analyzed to find out the tsunami vulnerability zone area that has occurred along the coast of Cipatujah Beach, Tasikmalaya Regency, West Java.

Measurement of field data in the form of slope data using GPS, geological compass and scale sticks, and water pass hose. Determination of the location of field measurements using a purposive sampling method that is at 12 points that are considered to have represented the study area, where these 12 points have covered the area of cliffs, ramps, river mouths, and also a mixture of cliffs and ramps. The beach slope data is measured with the distance of each measurement 10 meters horizontally with 3 times the measurement at each point.

Data processing carried out in this study consisted of several stages that began data preparation, the process of tsunami modeling and bathymetry processing as well as the zoning area of vulnerability from the tsunami range. Data preparation is carried out through the verification process of field beach slope values and models using Observation Standard Deviation (RSR). After that bathymetry data, high point data, earthquake parameter data, tidal data, measurement location points. Bathymetry data and high points are exported in .xyz format. In this study, using 2 layers with different grid sizes, 01 and 02 as input code.

Table 1. Boundary Model Limits and Grid Sizes

\begin{tabular}{|c|c|c|c|}
\hline No & Latitude & Longitude & Grid Size $\left(\mathrm{km}^{2}\right)$ \\
\hline 1 & $6,6479^{\circ}-12,0479^{\circ}$ & $105,3605^{\circ}-111,6645^{\circ}$ & $415.145,41$ \\
\hline 2 & $7,6141^{\circ}-8,0471^{\circ}$ & $107,8940^{\circ}-108,4585^{\circ}$ & $2.539,87$ \\
\hline
\end{tabular}

Earthquake parameter data used as input to COMCOT v 1.7 is Java 17 July 2006 earthquake data. The earthquake parameter data is the USGS Harvard University earthquake data which has been modeled for earthquake parameters as a single fault ${ }^{11}$. The following are data on the July 17, 2006, earthquake of USGS publication. 
Table 2. West Java Earthquake Parameter July 17, 2006

\begin{tabular}{|c|c|c|c|c|c|c|c|c|c|c|}
\hline Segment & Mw & \multicolumn{2}{|c|}{$\begin{array}{c}\text { Epicenter } \\
\text { Long }\end{array}$} & $\begin{array}{c}\text { Depth } \\
(\mathrm{km})\end{array}$ & $\begin{array}{c}\text { Strike } \\
\left({ }^{\circ}\right)\end{array}$ & $\begin{array}{c}\text { Dip } \\
\left({ }^{\circ}\right)\end{array}$ & $\begin{array}{c}\text { Slip } \\
\left({ }^{\circ}\right)\end{array}$ & $\begin{array}{c}\text { L } \\
(\mathrm{km})\end{array}$ & $\begin{array}{c}\text { W } \\
(\mathrm{km})\end{array}$ & $\begin{array}{c}\text { D } \\
(\mathrm{m})\end{array}$ \\
\hline Single & 7.8 & 107.419 & -9.284 & 10.0 & 289 & 10 & 95 & 200 & 80 & 10 \\
\hline
\end{tabular}

Tidal data to be inputted is the Mean Sea Level (MSL) value of the digital tidal data of the Pamayangsari Tidal Station, TPI Pamayangsari, Cipatujah, Tasikmalaya by BIG in January - October 2019 for the Java 17 July 2006 tsunami tidal scenario. retroactively processed using the Least Square method. The Least Square method is a method used for tidal calculations that use the principle of minimizing the tidal elevation equation, so that a simultaneous equation is obtained which is then solved by a numerical method to obtain the tidal component ${ }^{5}$. The Least Square method used consists of ERGTIDE, ERGRAM, and gERGELV.

In this study to determine the tsunami propagation time required measurement points consisting of longitude and latitude coordinate data as a tide station. The tide station is then stored in the name ts_location.dat in the COMCOT v 1.7 folder.

Table 3. Coordinate Point for Measurement of Tsunami Wave Height

\begin{tabular}{ccc}
\hline Point & Latitude & Longitude \\
\hline 1 & -9.0719 & 107.5686 \\
2 & -8.8167 & 107.6891 \\
3 & -8.5793 & 107.7792 \\
4 & -8.3326 & 107.8533 \\
5 & -8.0531 & 107.9338 \\
6 & -7.8151 & 107.0001 \\
\hline
\end{tabular}

After inputting the model is complete, proceed with a tsunami generation simulation with COMCOT v 1.7 software so that the zmax value is generated as input in the MATLAB software. After obtaining the coverage area by using the plot_flowdepth feature in MATLAB, proceed with making a map of the coverage area and vulnerability zone map using the Arc Map tool.

The method used in this verification and validation stage is the Observation Standard Deviation (RSR). RSR is an indicator that is generally used to determine the value of the model error in a static manner ${ }^{9}$. The equation used in expressing RSR values is as follows:

$$
\operatorname{RSR}=\frac{R M S E}{\operatorname{STDEV} V_{o b s}}=\frac{\left[\sqrt{\left(\sum \frac{D-M)^{2}}{n}\right.}\right]}{\left[\sqrt{\left(\sum\left(\left(D-\sum D\right)^{2))} / n\right]\right.}\right.}
$$

Keterangan :

$\mathrm{D}=$ Run upin the field

$\mathrm{M}=$ Run upmodel results

$\mathrm{n}=$ The amount of data

The criteria ${ }^{14}$ used are:

$\begin{array}{ll}0<\text { RSR }<0,5 & \text { very good } \\ 0,5<\text { RSR }<0,6 & \text { good } \\ 0,6<\text { RSR }<0,7 & \text { bad } \\ \text { RSR }>0,7 & \text { very bad }\end{array}$




\section{RESULTS AND DISCUSSION \\ Initian Tsunami Conditions}

In the initial conditions of the tsunami (fig 1), the highest surface elevation value of zmax was 4.1270 meters, the lowest surface elevation of zmin was -2.18 meters, and the wave velocity of cmax was $3.9206 \mathrm{~m} / \mathrm{s}$. Sea lever rise variation in the initial condition depends on the earthquake strength and epicenter depth.

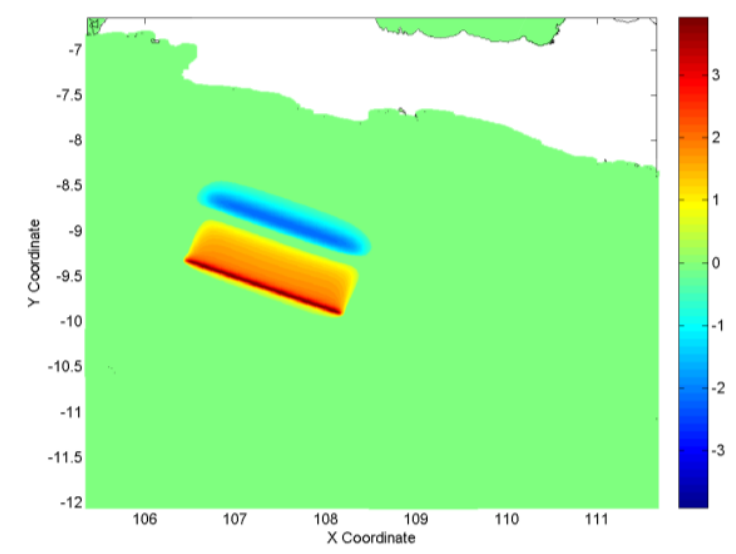

Fig. 1 : Initial Condition of the Java Earthquake Tsunami July 17, 2006

\section{Tsunami Travel Time}

Based on the results of processing ts_recordxx, shows the amplitude and time of propagation of tsunami waves that occur at each observation point (ts_location). It can be seen that the initial occurrence of tsunami wave propagation starts from ts_location 1 which is near the source of the earthquake to ts_location 6 located near the study site. The ts_location 6 point is the point that has the highest wave amplitude propagation record compared to the other points (Fig 2). That is because the location of the ts_location point in the waters of the sea bottom shall cause a tsunami wave that will reach the mainland to change shape. Tsunami waves at homogeneous depth change shape both wavelength and height, this is due to the nonlinear nature of the tsunami wave, and if the tsunami wave enters a shallow area, the height will be enlarged due to the shoaling effect and shrink when itbreaks ${ }^{20}$. Also, another effect of the superficial effect on waves is to cause the wave velocity to decrease along with the decrease in sea depth so that it affects the peak of the waves in shallow water moving more slowly than the wave peaks in deeper water ${ }^{2}$. This can be seen in the travel time and maximum height of the tsunami (Table 4), where at ts_location 6 the maximum wave height occurs in the 65th minute, slower than other ts_location.

Table 4. Tsunami Travel Time and Maximum Tsunami Altitude

\begin{tabular}{cccccc}
\hline \multirow{2}{*}{ Ts_location } & \multicolumn{2}{c}{ Coordinate } & ts_location & Z max & Zmaxperiod(hour:minutet:second) \\
\cline { 2 - 5 } & Longitude & Latitude & $\begin{array}{c}\text { depter) } \\
\text { (meter) }\end{array}$ & Zmaxp \\
\hline 1 & 107.568569 & -9.071963 & $-6005,79$ & 2.1122 & $00: 05: 56$ \\
2 & 107.689216 & -8.816796 & $-6584,39$ & 2.0976 & $00: 09: 18$ \\
3 & 107.779227 & -8.579399 & $-5889,35$ & 1.7603 & $00: 12: 05$ \\
4 & 107.853039 & -8.332682 & $-4632,4$ & 1.4574 & $00: 14: 37$ \\
5 & 107.933869 & -8.053190 & $-2977,32$ & 1.7149 & $00: 17: 53$ \\
6 & 108.000140 & -7.815159 & $-915,11$ & 2.7745 & $01: 05: 32$ \\
\hline
\end{tabular}

Keterangan :

Zmax = Maximum tsunami wave height from MSL

$\mathrm{Zmax}$ time $=$ The time when the maximum wave occurs 


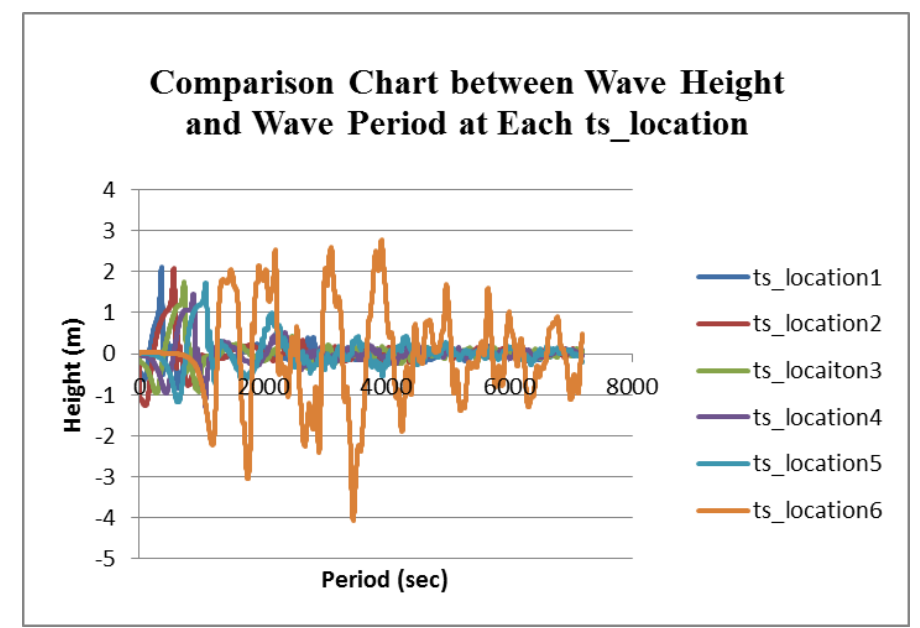

Fig. 2 : Graph Comparison of Periods and Amplitudes of Tsunami Waves at Each ts_location Point

The maximum tsunami height distribution resulting from the plot_zmax.m feature shows that the maximum tsunami wave reaches $5 \mathrm{~m}$. On layer 1, we can see maximum tsunami distribution in the entire south coast of Java in the Pameungpeuk, Pangandaran, Cilacap and Kebumen regions which produce higher maximum waves than otherregions ${ }^{1,7}$, which need to be seen before in the Pangandaran area of high distribution the maximum reaches $4 \mathrm{~m}$ and in theKebumen region, it reaches $5 \mathrm{~m}$. On layer 2, we can see the Tasikmalaya Regency on the west side including the Cipatujah region and the east side have a maximum wave height higher than the type of the middle Tasikmalaya Regency area. This is influenced by the sloping form of the seabed on the west and east sides of Tasikmalaya Regency. In the form of the seafloor, sloping waves will experience shoaling effects and also the presence of refraction or changes in wave direction, this causes the energy and height of the tsunami waves to experience enlargement and change in direction following thecoastline ${ }^{4}$.
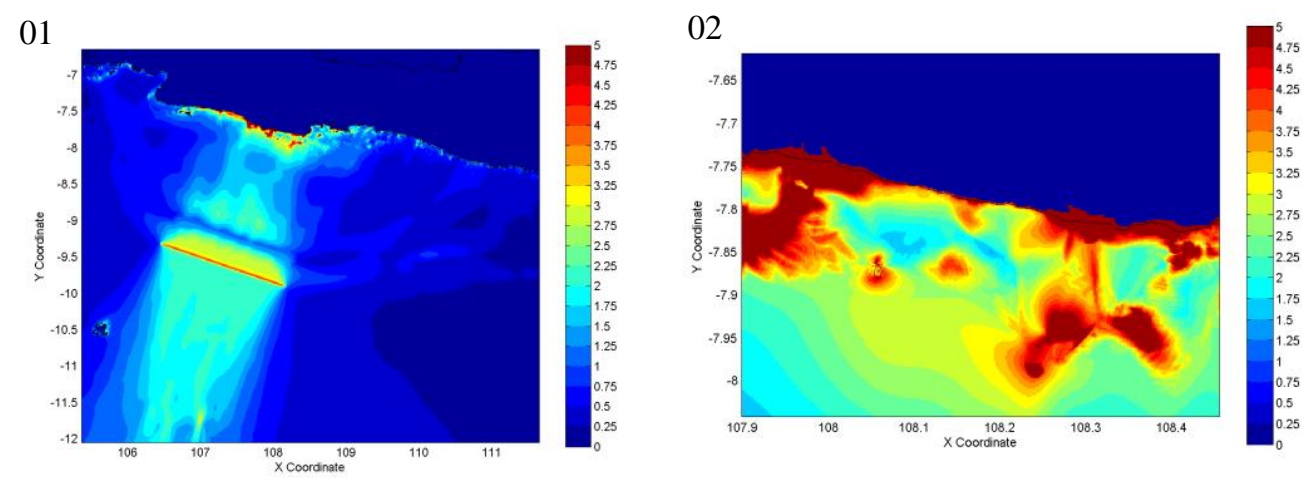

Fig. 3 : Zmax Distribution on Layer 01 and Layer 02

\section{Tsunami Inundation and Vulnerability Zone}

Tsunami run-up map divided into 3 categories of inundation height (Fig4), obtained in Tasikmalaya District experiencing a tsunami inundation with a total area of $22.37 \mathrm{~km}^{2}$. In the area of Cipatujah experienced a tsunami inundation with a total area of $11.64 \mathrm{~km}^{2}$. The value of the tsunami range is obtained through the plot_flowdepth.m feature, which is a high value of tsunami run-up, then processed into a tsunami range map so that a maximum inundation height of 6.115 meters is obtained and the maximum distance of the tsunami range is 1.891 kilometers. The wave run-up in the Cipatujah region is affected by the height of the region and the slope of the coast. The height of the area significantly influences the extent of the tsunami coverage area. The lower the position of an area, the greater the 
potential of the region affected by the tsunami, while the slope affects the distance of the tsunami wave range.

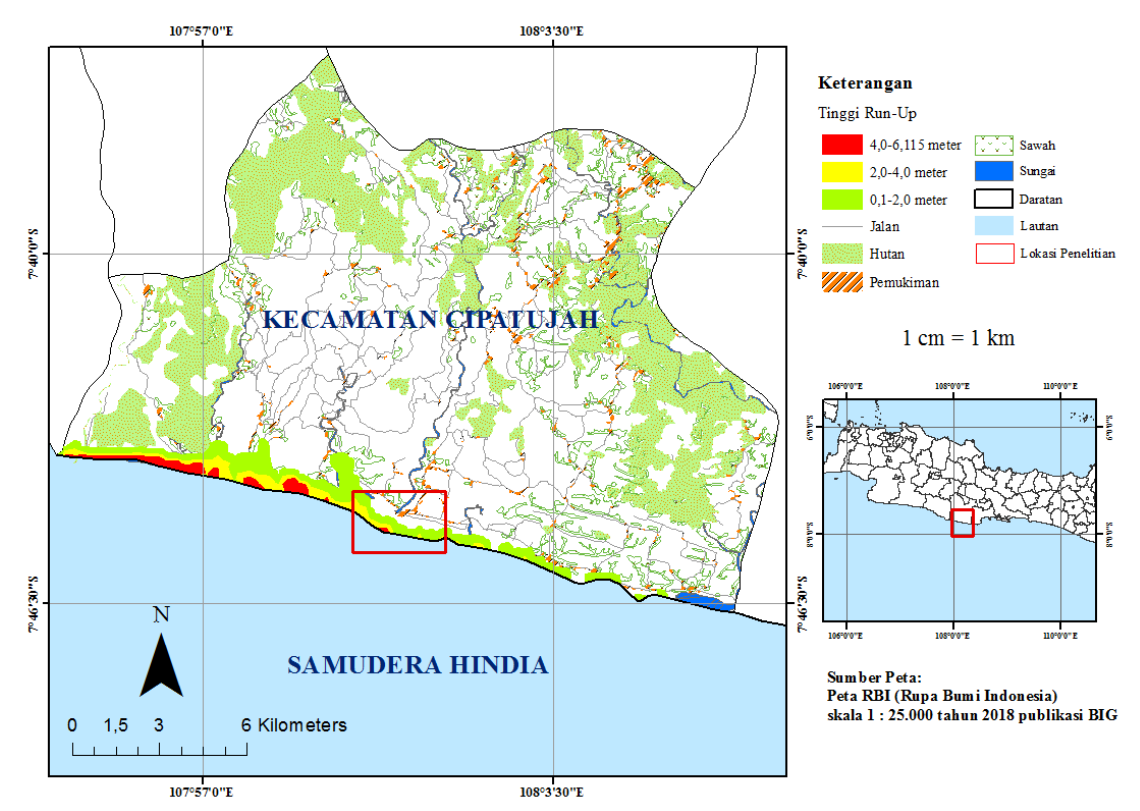

Fig. 4. Tsunami Run-Up Map in Cipatujah, Tasikmalaya District

Table 5. Area and Maximum Distance of Tsunami Run-Up in Cipatujah

\begin{tabular}{ccc}
\hline $\begin{array}{c}\text { Run-Up Heights } \\
(\mathrm{m})\end{array}$ & Area $\left(\mathrm{km}^{2}\right)$ & Maximum Reach Range $(\mathrm{km})$ \\
\hline $0,1-2,0$ & 7,4112 & 1,891 \\
$2,0-4,0$ & 2,5695 & 0,770 \\
$4,0-6,115$ & 1,6635 & 0,512 \\
\hline Total & 11,6442 & 3,173 \\
\hline
\end{tabular}

Based on the simulation of the tsunami model and the known high run-up values as well as the extent of tsunami coverage, a vulnerability zone can be formed which is divided into 3 classes (Fig 5). Vulnerability zone consisting of three disaster-prone areas ${ }^{12}$ based on high inundation namely: low disaster-prone areas, medium disaster-prone areas, and high disaster-prone areas ${ }^{10}$. Based on the results obtained, a low disaster-prone area is an area with a pool of less than 1 meter, including an area quite far from the coastline, with an area of $10.007 \mathrm{~km}^{2}$ in Tasikmalaya Regency, and $5.473 \mathrm{~km}^{2}$ in Cipatujah. A medium disaster-prone area where there are inundations between 1 and 3 meters, including areas that are close to the coastline, with an area of $6,621 \mathrm{~km}^{2}$ in Tasikmalaya Regency and 3,362 in Cipatujah. Whereas high disaster-prone areas were areas that have a pool of more than 3 meters, including the area closest to the coastline, with an area of $5,893 \mathrm{~km}^{2}$ in Tasikmalaya Regency and 2,883 in Cipatujah. In high disaster-prone areas, this is the area that has the greatest impact of tsunami waves compared to other hazard-prone areas. In high disaster-prone areas is an area that has the greatest impact of tsunami waves compared to other vulnerable areas and is an area with low elevation. This happens because the level of vulnerability of an area to a tsunami wave is influenced by surface elevation, the lower the elevation of an area, the higher the level of vulnerability ${ }^{8}$. Based on the mapping of coverage areas and also tsunami vulnerability zone, it can be seen that the majority of tsunami-affected areas include residential areas, rice fields, plantations, forests, roads, vacant land in the area of Cipatujah, Tasikmalaya Regency. 


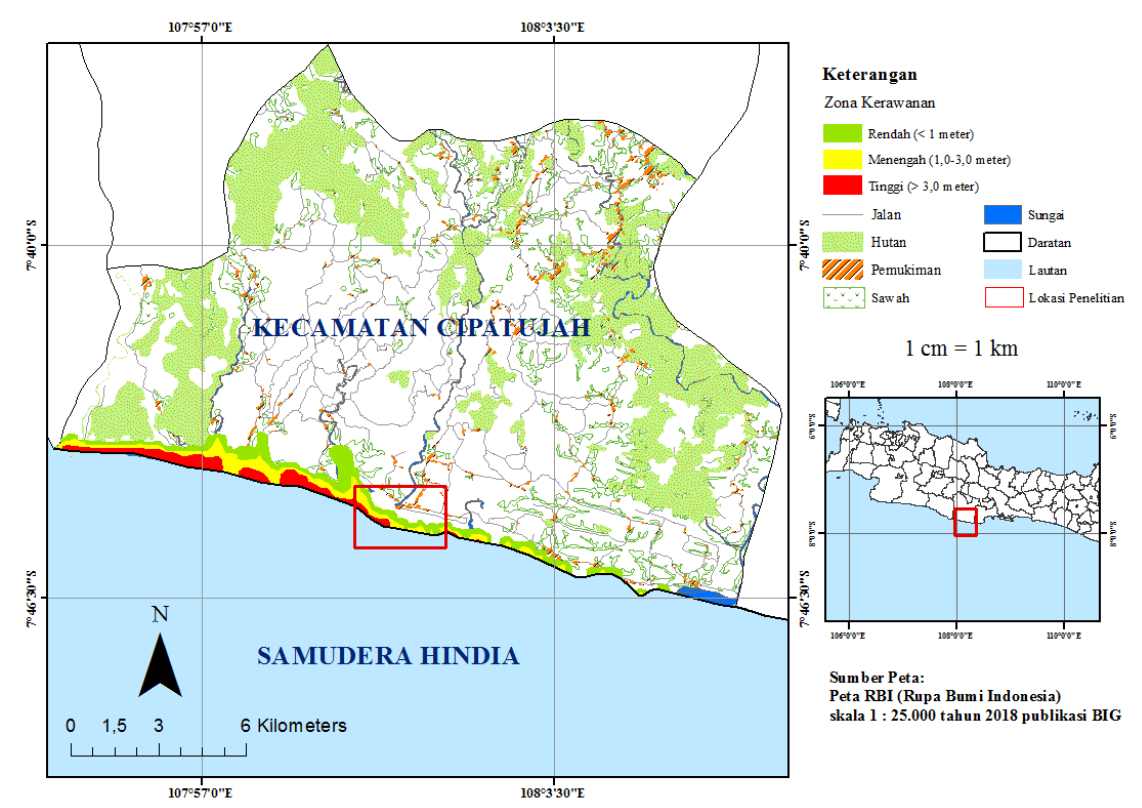

Fig. 5. Tsunami Hazard Map in Cipatujah, Tasikmalaya District

Table 6. Total Zoning Area of Tsunami Hazard in Cipatujah

\begin{tabular}{cc}
\hline Hazard zone & $\mathrm{Area}\left(\mathrm{km}^{2}\right)$ \\
\hline Low & 5,473 \\
Medium & 3,362 \\
High & 2,883 \\
\hline Total & 11,644 \\
\hline
\end{tabular}

\section{Model Validation}

The results of the model data are then verified and validated by the results ofresearch ${ }^{6,13} \operatorname{combined~with~}$ the Meteorological, Climatology, and Geophysics Agency data as well as field observational data ${ }^{11}$ conducted by from BPBD, BPPT, and ITS. Run-up calculations using Field Survey Data are shown in Table 6 as follows:

Table 7. Calculation of Run-Up Verification

\begin{tabular}{|c|c|c|c|c|c|}
\hline \multicolumn{2}{|c|}{ Coordinate } & \multirow{2}{*}{$R$} & \multirow{2}{*}{$\mathrm{RM}$} & \multirow{2}{*}{$(\mathrm{R}-\mathrm{Rm})^{2}$} & \multirow{2}{*}{$\left(\mathrm{R}-\sum \mathrm{R}\right)^{2}$} \\
\hline Longitude & Latitute & & & & \\
\hline 107,91 & $-7,728$ & 3,331 & 3 & 0,1095 & 69,0062 \\
\hline 107,979 & $-7,74$ & 5,822 & 5 & 0,6756 & 33,8258 \\
\hline 108,164 & $-7,788$ & 2,485 & 2 & 0,2352 & 83,7774 \\
\hline & Total & & 10 & 1,0204 & 186,6095 \\
\hline \multicolumn{2}{|c|}{$\sigma D$} & & 7,8868 & & \\
\hline \multicolumn{2}{|c|}{$\sum\left((\mathrm{D}-\mathrm{M})^{\frac{2}{n}}\right)$} & & 1,1787 & & \\
\hline \multicolumn{2}{|c|}{ RMSE } & & 0,5832 & & \\
\hline \multicolumn{2}{|c|}{ RSR } & & 0,0739 & & \\
\hline
\end{tabular}

The values in Table 6, are described for the calculation of verification and validation by the RSR method as follows:

$$
\sigma D=\sqrt{\frac{\left(\mathrm{R}-\sum \mathrm{R}\right)^{2}}{n}}=\sqrt{\frac{186,6095}{3}}=7,8868
$$




$$
\begin{gathered}
\mathrm{RMSE}=\sqrt{\frac{(\mathrm{R}-\mathrm{M})^{2}}{n}}=\sqrt{\frac{1,02047}{3}}=0,5832 \\
\mathrm{RSR}=\frac{R M S E}{\sigma D}=\frac{0,5832}{7,8868}=0,0739
\end{gathered}
$$

\section{CONCLUSION}

Based on research that has been done, the following conclusions are obtained:

1. The Java Tsunami of July 17,2006 , had an initial wave velocity of $3.92 \mathrm{~m} / \mathrm{s}$, the propagation of the tsunami began with receding conditions along the coast which occurred at the 19th minute and followed by the tsunami waves at the 27th minute. In the 65th minute, a maximum amplitude of 2.77 meters occurred towards the Cipatujah Coastal District, Tasikmalaya Regency.

2. The maximum run-up height is 6,115 meters and the maximum tsunami range is 1,891 kilometers from the coastline. The extent of wave run-ups that occurred in the Tasikmalaya Regency area was $22.37 \mathrm{~km}^{2}$ and the Cipatujah area was $11.64 \mathrm{~km}^{2}$. Whereas the zoning of vulnerability in the areas of Tasikmalaya and Cipatujah regencies is divided into 3 categories: Low Hazard Zone, Medium Hazard Zone, and High Hazard Zone.

\section{REFERENCES}

1. Aeda, S.A., Saputro S.and Subardjo P., Simulasi Penjalaran dan Penentuan Run-Up Gelombang Tsunami di Teluk Pangandaran Jawa Barat, Jurnal Oseanografi., 6 (1), 254 (2017)

2. Agustino, O., Prasetyawan I.B. and Ismanto A., Kajian Penjalaran dan Transformasi Gelombang di Perairan Tanjung Kelian Kabupaten Bangka Barat, Jurnal Oseanografi., 3 (2), 236 (2014)

3. Andreas, H., Abidin H.Z., Kato T.,Ito T., Haryoho.,Kusuma M.A., Irwan., Sidiq T.P., Nurmaulia S.L.and Gamal M., Lesson From Juli 17 2006 South of Java Earthquake : a Note for INATEWS,Internasional Conference on Tsunami Warning (ICTW), Bali, 7 (2008)

4. Bryant, E., Tsunami : The Underrated Hazard (Second Edition), Praxis Publishing Ltd,Chichester,102(2008)

5. Denafiar, F.S., Nugraha A.L. and Awaluddin M., Pembuatan Program Penentuan Konstanta Harmonik dan Prediksi Data Pasang Surut dengan Menggunakan Visual Basic For Application (VBA) Ms. Excel,Jurnal Geodesi Undip., 6 (4), 295 (2017)

6. Fritz, H.M., Kongko W., Moore A., McAdoo B., Goff J., Harbitz C., Uslu B., Kalligeris N., Suteja D., Kalsum K., Titox V., Gusman A., Latief H., Santoso E., Sujoko S., Djulkarnaen D., Sunendar H. andSynolakis C., Extreme Run-Up from the 17 July 2006 Java Tsunami,Geophysical Research Letters., 34 (1), 1(2006)

7. Hartanto, B.and Astriawati, N., Identifikasi Pendekatan Shallow Water Equation dalam Simulasi 2D Gelombang Tsunami di Pantai Keburuhan Purworejo,Majalah Ilmiah Bahari Jogja (MIBJ)., 18 (1), 127(2020)

8. Helmi, M., Pholandani Y.H., Setiyono H., Wirasatriya A., Atmodjo W., Widyaratih R. and Suryoputro A.A.D., Intergrated Approach of Tsunami Vulnerability Assessment at Coastal Area of Kalianda Sub District, South Lampung District, Lampung Province, Indonesia, International Journal of Scientific \& Technology Research., 9 (3), 1803 (2020)

9. Hoover, S.V. and Perry R.F., Simulation a Problem Solving Approach, Addison-Wesley, New York(1989) 
10.Kongko, W,. South Java Tsunami Model Using Highly Resolved Data And Probable Tsunamigenic Sources, Universitat Hannover, Hannover, 314(2011)

11.Kongko, W., Suranto., Chaeroni., Aprijanto., Zikra and Sujantoko., Rapid Survey on Tsunami Jawa 17 July 2006, BPDP-BPPT dan Institut Teknologi, Surabaya, 18(2006)

12.Maemunah, I., Sulaeman C. and Robiana R., Identifikasi Potensi Kerawanan Tsunami di Wilayah Kabupaten Jember, Jawa Timur,Jurnal Lingkungan dan Bencana Geologi., 2 (2), 141(2011)

13.Mori, J., Mooner W.D., Afnimar., Kurniawan S., Anaya A.I. and Widiyantoro S., The 17 July 2006 Tsunami Earthquake in West Java, Indonesia,Seismological Research Letters., 78 (2), 201(2006)

14.Moriasi, D.N., Arnold J.G.M.W., Van Liew R.L., Binger R.D., Hatmel T.L. and Veith., Model Evaluation Guidelines for Systematic Quantification of Accuracy in Watershed Simulatioin, American Society of Agricultural and Biological Engineers., 50, 885 (2007)

15.Rahanjani, Y.E.andSetianto S.A., Pemanfaatan Citra Digital Elevation Model (DEM) Untuk Studi Evolusi Geomorfologi Gunung Api Merapi Sebelum dan Setelah Erupsi Gunung Api Merapi 2010,Seminar NasionalInformatika 2012(2012)

16.Rusli, I. and R. Ariska., Pemodelan Tsunami Sebagai Bahan Mitigasi Bencana Studi Kasus Sumenep dan Kepulauannya, Jurnal Neutrino., 2 (2), 164(2010)

17.Sugianto D.N., Ismanto A. And Ferawati A. Analisis Transformasi dan Spektrum Gelombang di Perairan Balongan, Indramayu, Jawa Barat, Seminar Nasional Tahunan ke-V Hasil-Hasil Penelitian Perikanan dan Kelautan, 702 (2016)

18.Sugiyono., Metode Penelitian Kuantitatif, Kualitatif dan R\&D,Alfabeta, Bandung, 236 (2011)

19.Sunarjo., G, Taufik M. and Sugeng P., Gempa Bumi Edisi Populer, Badan Meteorologi Klimatologi dan Geofisika, Jakarta, 236 (2012)

20.Triatmadja, R., Model Matematik Teknik Pantai. Beta Offset, Yogyakarta (2009)

21.Triatmodjo, B., TeknikPantai, Beta Offset, Yogyakarta, 397 (1999)

22.Triyono, R., Prasetya T., Daryono., Anugrah S.D., Sudrajat A., Setiyono U., Gunawan I., Proyobudi., Yatimantoro T., Hidayanti., Anggraini S., R.H. Rahayu R.H., Yogaswara D.S., Hawati P., Apriani M., Julius A.M., Harvan M., Simangunaong G.and Kriswinarso T., Katalog Tsunami Indonesia Tahun 416 - 2018, Badan Meteorologi dan Geofisika, Jakarta, 91 (2019) 